\title{
TITLE: Academisation: who now holds the key to the secret garden?
}

\section{ABSTRACT}

This paper aims to demonstrate the hazard of an education system controlled by any one group, in this case governments, by examining the recent drive for the academisation of English state schools. This paper highlights the need for education's independence from political control. The once 'secret garden' of the curriculum is now firmly in the government's grasp. Academies were introduced in England in 2000 by the Labour government; originally called City Academies, they were claimed to break the cycle of underperformance and low expectation of failing inner city schools. But they are now promoted as the only means of providing 'outstanding' education. I argue that the current drive for academisation forms part of the market-oriented narrative that believes market forces offer the best solution to all the needs of society. As well as delivering substantial changes in governance and accountability, Academisation conceals a radical shift in education's purpose, yet it is being pushed through without real debate. The academisation process offers an insight into how governments can and do use state apparatus to ignore, subvert, and diminish opposition. To highlight this, I use Steven Lukes' conceptualisation of power: the public, the hidden, and the invisible. 


\section{Academisation: who now holds the key to the secret garden?}

\section{Introduction}

The aim of this paper is to demonstrate the hazard of an education system controlled by any one group, by examining successive British governments' drive for the academisation of English state schools. This paper will highlight - through analysing aspects of the academisation process - how any 'hegemonic group' (politicians in the present case) with sole control can initiate and push through radical changes to education policy motivated by their ideological preferences. The paper illustrates how governments, as the hegemonic institution of power, rather than engaging in an open and transparent public debate, can utilise their power to dismiss and subvert opposition, as well as in Gramscian terms project their ideology upon the subordinated (those not aligned to the interests of the ruling elite) who come to see through false consciousness those interests as 'common sense' and 'natural', even though they do not reflect their best interests. It is acknowledged however, that education is inherently political; hegemonic elites such as the clergy, monarchy, politicians (and more recently corporations and philanthropists) have controlled and sought control of schooling and the content of the curricula in order to maintain their hegemony.

I begin by providing an historical contextualisation of Academies, and then demonstrate the political 'capture' of education. The current drive for academisation arguably represents the most radical change put forward by any government since the 1902 Education Act, achieved without 'real' public debate, or clear evidence for the success of Academies. In the discussion I use Steven Lukes' conceptualisation of power: the public, the hidden, and the invisible, to 
analyse the influence of power in the academisation process, and the possible societal consequences of academisation. Arguably the academisation process also represents 'privatisation' of schools through the back door; by privatisation I mean schools being run on corporate ethos and structures. However, although the paper speaks of a 'secret' privatisation of English state schools its purpose is not to explore whether schools should be privatised (on this see the Ranson (1993; 1995), and Tooley (1995) debate).

\section{Background}

The UK has a parliamentary democracy but most of the power is concentrated de facto in the hands of the Executive: Parliament generally rubber stamps decisions of government and the promulgation of laws. Governments tightly control debates (with politicians 'whipped into subservience' (Jeffs and Smith, 2002). This is particularly discomfiting given that since 1945 no party in the UK has gained more than a 50\% share of the vote (Kimber, 2012), and governments have been elected by a minority of the electorate. The situation is compounded because most citizens are largely passive and apathetic to the political process - behaving as an audience selecting from options provided by the elite, rather than participating in the formulation of policy and the decision-making process of government (Manin, 1997). Under such circumstances in the UK, the 'tyranny' of the minority is more likely than that of the majority.

\section{Academy Schools}


There is much that has been written about Academies: their history and political context (Walford, 2014); evidence regarding their effectiveness (Angel Solutions Ltd, 2016; Beckett, 2007; Briggs and Simons, 2014; Gorard, 2014; PwC, 2008; Worth, 2015); improving education provision through the extension of the market and the creation of diverse provision (Gunter and McGinity, 2014); comparative analysis with Swedish independent grant-maintained schools (West, 2014) and US Charter schools (Goldring and Mavrogordato, 2011); and social justice implications (Francis et al., 2014; Green et al., 2015; Perry and Francis, 2010; Walford, 2014); and the commodification of the education system with the advent of corporate structuring (Ball, 2004, 2007; Connell, 2013; Husbands, 2016). However, with the exception of Hatcher $(2008,2011)$, exposing how state-driven governance networks are designed to construct compliance and marginalise dissent, there is little that has been written about the power at play in the drive toward academisation.

So, what are Academies? Unlike state maintained schools, Academies are outside the control of Local Education Authorities (LA), and are:

- under direct contract with the Secretary of State for Education

- permitted to prioritise up to $10 \%$ of the pupils by aptitude

- free to disburse their funds as they wish

- free to set their own pay and conditions for staff

- and do not have to employ only those teachers with Qualified Teacher Status (QTS) In addition

- new Academies must now join existing chains, encouraging the formation of large multi-academy trusts (MATs), in which schools can be 100 s of miles apart 
- hold large cash reserves - that are not being spent on raising standards of the education of children

Academies were introduced in England in 2000 by a Labour Government, although their antecedents can be traced to City Technology Colleges (CTC) announced by Conservative Education Secretary Kenneth Baker in 1986. These were purported to develop enterprise, selfreliance and responsibility, and broaden parental choice. Originally called City Academies in Labour's Learning and Skills Act 2000, Academies were claimed to tackle social injustice by 'breaking the cycle of underperformance and low expectation' of perceived to be failing inner city schools (Blunkett, 2010). But they have now come to be promoted as the only means of providing 'outstanding' education. By January 2016, 65.5 percent of all secondary pupils and 19.5 percent of primary pupils in England were attending academised schools (DfE, 2016: 3).

The official discourse around Academies and Free Schools is one of providing excellence and addressing failure. In the UK it is likely that for the majority of people the word 'academy' will conjure an image of excellence and elitism. There is an association with societies or institutions 'of distinguished scholars and artists or scientists [which] promote and maintain standards in [their] particular field: the Royal Academy of Arts' (Oxford Dictionaries). The term 'free' implies something that has been 'unshackled' or 'liberated' from something bad - in this case schools from the control of local authorities. And the latest offering in the proliferation of liberated schools, the Studio school, provides an impression of a creative institution. This false conceptualisation of Academies and Free Schools with 'excellence' and 'creativity' (given that there is little evidence that they are better than state maintained schools) contributes to the difficulty of exploring and exposing their weaknesses or the true direction of the policies 
that have produced them. This is unsurprising; after all, who could oppose an Academy when academisation is framed as addressing failure. Such a narrative can create confusion in the public's perception of the benefits of Academies, and may explain the lack of sustained momentum or cohesion between the various groups who resist academisation - be they parents, teachers, academics or others.

The academisation of English state schools 'is about major root and branch changes to the purposes of public education through dismantling the post-war settlement' (Gunter, 2011: 1); it is underpinned by a market-oriented ideology which has sought to restore the dominance of the private sector. This world view sees the market approach as the most effective and efficient mechanism for resolving all the needs of society. The academisation process needs to be seen in light of the 'learning economy'- serving a desire for market competitiveness and a skills-based agenda. As the former Labour Prime Minister Tony Blair (1998) put it: 'Education is the best economic policy we have' (in Martin, 2003: 567). Under the 'learning economy' hegemony successive governments have viewed education as an important lever for economic growth and global competitiveness. Skills are equated with economic success. According to Hatcher,

[t]he most fundamental legacy of the Blair government in school education in England is to have established the production of 'human capital' for the competitiveness of the British economy as the master narrative of policy (Hatcher 2008, 665).

This contrasts with the social justice agenda which informed education policy before the 1980s. It is only right that the future workforce should be equipped with 'skills' to keep pace 
with the revolutions in technology affecting how we live and work, but the problem with this is that it is too narrowly viewed through the lens of science and technology. 'Yet the challenges facing us today are as much human and societal as they are technical and scientific' (Cannadine, 2017).

\section{The Political Capture of the Secret Garden}

Since the early 1980s the dominant trend within English education and training has seen successive governments having increased influence in the design, control and implementation of education policy (Keep 2006, 48). From having a limited and peripheral role in education and training prior to 1981, compulsory education in England has become one of the most centrally-controlled education systems in the world (Bassey, 2003). This has been matched by an unparalleled pace and scale of change since 1987 (Jenkins 1995 in Keep, 2006: 50). The weakening of education's independence from political direction began in 1976 by the then Labour Prime Minister James Callaghan's 'Great Debate' speech on education at Ruskin College, Oxford. Callaghan was addressing the Black Papers (published between 1969-1977). The Black Papers, though not opposed to progressive education, attacked its supposed excesses - and a perception that education was responsible for society's problems.

Prior to Callaghan's speech the curriculum had been referred to, in 1960 by Conservative Education Minister David Eccles, as a 'secret garden' into which politicians should not seek to venture. This was a reflection and recognition of the intent of the 1944 Education Act, the first clause of which stated that while the minister has the ultimate responsibility for promoting education, the local education authorities and teachers would develop the content. 
The 1960 s are commonly assessed as marking a striking growth in teacher autonomy, especially in relation to the curriculum. ... [T] he received (and official view) of the 1960s was that the curriculum (or what went on in schools) was the specific responsibility of the teachers - not of the local authorities (though their role was unclear) and certainly not the state - or the central government (Simon 1991, in Bassey, 2003: 9).

This was the consensus when it came to education: it was a no-go area for local and central government. However, in his 'Great Debate' speech, Callaghan suggested that no one could claim 'exclusive right' in the domain of education - that the teaching profession should not seek sole control of the 'secret garden' of the curriculum, and that there were other stakeholders (parents, industry and government) whose opinions were needed to address the question of formulating and expressing the purpose of education, as well as the standards to be met. His argument was that given everyone had some experience of education, everyone had something to contribute to the debate. Even though Callaghan was not interested in dismantling the comprehensive education system, his speech ushered in the era of testing, school league tables, and accountability as articulated by Cox and Boyson (1977: 8-10). Callaghan thus allowed politicians to claim a popular mandate for what they were doing, and it made education a much more partisan affair.

Callaghan was right however: no-one should have sole ownership of education policy; education is far too important to be vested in the hands of a select few, expert or otherwise. However, 42 years on from his speech control of the 'secret garden' has transferred from education experts to politicians and their political agendas. Today it has become normal for 
central government to interfere with the curriculum. This trend towards greater governmental control of education and training is paradoxical given that it began under a Conservative administration which, in pursuit of market-oriented ideals, was in favour of reducing the role of the state and sought greater emphasis on market-based solutions to public policy (Gamble 1994; Jenkins 1995, in Keep 2006). However, the only way to bring about this ideological shift was to entertain this paradox.

\section{Schools: the current push for Academisation}

The current drive for the academisation of the English state maintained schools represents the most radical change put forward by any government since the 1902 Education Act and has been achieved, I contend, without serious public debate. The case for full academisation of the English compulsory education system was made by Policy Exchange, a think tank set up by former Conservative Education Secretary Michael Gove, which advocated in its report Primary Focus (Briggs and Simons, 2014) that all primary schools should convert to Academies, and secondary schools should follow suit. Briggs and Simons, the authors, assert that it is the most effective way to combat the 'perfect storm' that is looming ahead: a fifth of primary school headteachers approaching retirement, cuts in funding, and the introduction of a rigorous new national curriculum and assessment systems, which will increase pressure on teachers. Part of this 'perfect storm' however is an exaggeration as at any given time about $20 \%$ of primary headteachers are aged 50-59, and can be described as 'approaching retirement'. 
Under the Education and Adoption Act 2016 all schools rated 'inadequate' by Ofsted (the Office for Standards in Education, Children's Services and Skills - responsible for inspecting a range of educational institutions in England) will have to become an Academy. New powers will allow the Department of Education to change the leadership of failing schools and stop campaigners 'obstructing' takeovers. The former Education Secretary Nicky Morgan (Weale, 2015) defined the concept of 'coasting schools' as those failing to ensure that $60 \%$ of pupils get five good GCSE grades ( $\left.A^{*}-C\right)$ including Maths and English. In addition, from 2016 schools are also to be judged on pupils' progress from the beginning of secondary school to their GCSEs; any school not scoring highly on the government's new accountability measure Progress 8 will also be classed as coasting. For primary schools the bar is even higher. Primary schools are required to ensure that $85 \%$ of 11 -year-olds achieve a Level 4 in reading, writing and Maths - raised from the previous intervention threshold of under $65 \%$, and a higher-thanaverage proportion of pupils failing to make expected progress. In addition, summer 2016 saw the introduction of more rigorous Standard Attainment Tests (SATs), which meant the scrapping of the Levels classification, replacing them with children's raw exam marks and comparisons with national averages as indicators of success/failure.

The former Conservative Prime Minister David Cameron's desire for zero tolerance on 'failure' and 'coasting' schools meant that even schools with the two highest ratings 'good' or 'outstanding' by the Ofsted can be forced to become Academies. For Cameron: those 'schools rated good at their last inspection - but which haven't been maintaining high standards since... are giving children "just enough" to avoid falling beneath our floor standards' would be forced to become a sponsored Academy (TES Reporter, 2015). Such language I argue surreptitiously frames success into failure - for even a school rated outstanding must do more, and if not, it 
could be regarded as 'coasting', and open to academisation.

However, barely a year passed and the ground shifted again, with the government's March 2016 White Paper: Education, Excellence, Everywhere, which sought to force academisation on all remaining state maintained schools by 2022 .

'The [...] White Paper [was] a decisively centralising White Paper, placing enormous power in the hands of the secretary of state. The localism of 1902 and 1944, with their belief in local government, and of 1988 , with its belief in parents, has been replaced by a faith in the corporate leadership of MATs' (Husbands 2016).

However, after much opposition especially from Conservative MPs and Conservative Local Councillors, the Government, in practice but not in ideology, back-tracked on forced academisation, and on 27 October 2016 dropped the Education Bill altogether, with Prime Minister Theresa May favouring grammar schools and selection, as opposed to forced academisation of all schools.

\section{Evidence for the success of Academies}

Considerable emphasis is given to the expectation that converting to Academy status will improve outcomes as a result of 'establishing collaborative practices around teaching and learning, supporting teachers and individual school leaders to focus on what happens in classrooms, and supporting a culture of continuous improvement and development' (Briggs and Simons, 2014: 10). But there are examples of excellent local authority (LA) maintained schools. So what prevents the Head Teachers of these schools from sharing their skills and expertise, or schools within different districts and boroughs from pooling their resources? 
Why can't LA schools become part of federations? Rather than looking at governance structures, governments should look at the characteristics of good schools, and these are not bound by any particular form of governance. But then this would undermine the official discourse on the advantages of becoming an Academy. Giving greater autonomy to Academies but not to maintained schools is deliberately denying those freedoms to maintained schools. The effect is to create an incentive for academisation in order to access greater freedoms.

In his foreword to Primary Focus Sir David Carter, then Regional Schools Commissioner for the South West of England, says that over a period of 17 years to 2014, standards in primary schools had improved in Maths and English, from 67\% (English) and 62\% (Maths) of children attaining Level 4 , to $89 \%$ and $86 \%$ respectively. However, because the Government has set higher standards from 2016, to $85 \%$ in each subject, the Primary Focus authors believe academisation is the best path to follow because they estimate 'as many as $20 \%$ of schools would not have reached that level this summer.' Anybody reading this would be befuddled: primary schools are currently achieving above government targets, yet the report estimates that 20\% will fail! Briggs and Simons (2014: 10) even acknowledge that: 'Academy status is not some sort of panacea' which will automatically lead to improvements. But for them 'it is clear that the creation of groups of schools collaborating together and sharing best practice is what is needed'; is this not spinning the truth to arrive at a conclusion which the evidence does not support?

The research so far has not produced consistent findings. Early reports were of modest but insignificant student progress (Machin and Wilson, 2009; PwC, 2008); however Worth (2015) found student progress in Academies to be no greater than in state maintained schools with 
similar characteristics, and Angel Solutions (2016) found the opposite. Furthermore, the Education Select Committee in January 2015 states that: 'Academisation is not always successful nor is it the only proven alternative for a struggling school (House of Commons Education Committee, 2015: 23), a point concurred with by Nick Gibb (2015), Minister of State for Schools. Moreover, Ofsted figures show that those schools which were rated inadequate are more likely to improve under their local authority than if forced to become an Academy.

\section{Privatisation through the back door?}

As Beckett (2007) argued 'if there was a Government policy characterised by spin rather than substantial evidence, it is the academies programme' - companies and rich individuals are persuaded to sponsor academies, with untruths being told in support of the academies project. Given the lack of evidence, there is a suspicion that the academisation of the English State school system represents a secret privatisation agenda, and the re-introduction of selection through the back door. This would fit in with the British Conservative Party's ideology of the market as being the most effective and efficient form of providing society's needs. Stephen Ball (2004) asserts that current policy discourse idealises and romanticises the private, 'while the bureau-professional regime of public welfare provision is consistently, and often unthinkingly, demonised.' In this world view, state schools/universities are seen as 'value/commodity producing enterprises' (Rikowski 2003, in ibid). At the school level, the emphasis of learning and teaching is attached to high-stakes testing, which comes at the expense of deep-knowledge learning, and to the homogenisation of curricula whose delivery is proscribed. Within this context, one can argue as Ball (2004) does, that educational processes are being rendered 'into metric form, into comparable performances' which serve 
to order them

into a form which is more readily privatised - that is, into a contractable form, into a form for cost and profit calculation, into a version of education which can be reduced to a commercial exchange based on output indicators, which can be monitored (ibid.)

Let us now consider the evidence for a 'privatisation' agenda. On any broad definition of privatisation the reality of academisation structures look remarkably corporate, and the policy direction keeps open the possibility of wholesale privatisation of Academy Trusts. A precedent exists in Sweden's friskola and US Charter Schools. Academies 'are institutions that have been withdrawn from collective democratic accountability and delivered over into the power of individuals and unaccountable institutions' (Wrigley 2009, 48). They are outside the control of Local Education Authorities, and because they are under direct contract with the Secretary of State for Education this means that it is easier for government to bypass local opposition, and hand out contracts to those organisations which fit its ideology. There is corporate structure which Ball (2013) argues is replacing local democratic oversight, and is radically changing our relationship to schools. A parallel exists with the now privatised utilities where, as customers, we can choose and change providers, and complain to a national watchdog when feeling aggrieved 'but with no direct, local participation or involvement, no say in our children's education (ibid.).

The Swedish privatisation of state schools may well act as a model for what recent Conservative governments have in mind further to full academisation and potential privatisation. Under the guise of choice, Sweden introduced an educational voucher system 
(skolpeng) in 1992. This enabled private schools to compete for students with public schools on an equal financial basis and with full public funding (Blomqvist 2004, 147). The move, inspired by the ideas of Friedman (1962) and Chubb and Moe (1990) was promoted as improving choice. Within a very short period of time, the education system was transformed from one that was publicly run but with little parental choice, to one of the most (neo)liberal education systems in the world (Blomqvist 2004, 148). However, research (Björklund et al 2005; Böhlmark and Lindahl 2007 and 2008, in Wiborg 2010, 14-15) has not been able to identify any positive effect of Free schools on greater educational attainment. Since the introduction of friskola, Sweden has seen a steep decline in its PISA rankings. This prompted the OECD in its report in May 2015 to recommend that Sweden undergo a root and branch education reform to restore its previously high educational standards. It is interesting to note that Finland, which nationalised all its schools and turned them into comprehensives over forty years ago, finds its students consistently ranked high in international comparisons such as the PISA grading.

\section{Discussion}

\section{Influence of power}

How has academisation been achieved? To answer this question I will use Steven Lukes' conceptualisation of power. One could argue that academisation is in fact about power and how power is exercised through policy and other routes. If one looks at the debate - or lack of it - around the academisation process one sees that those against academisation are thwarted at all stages of the process, and are made powerless. In 1974 Lukes, challenging Dahl (1961) 
and Polsby's (1963) idea of power, argued that power must be understood in terms not only of those who participate, but also of those who do not. For Lukes power has three dimensions: public or visible power, exercised through the use of political bodies, such as legislatures, local government bodies, local assemblies, or consultative forums; hidden power, which keeps issues off the agenda in decision making arenas (Bachrach and Baratz, 1962); and an insidious third, invisible power, through which the relatively powerless come to internalise and accept their condition. They might not be aware of nor act upon their interests. This insidious use of power prevents conflict from even arising. '[A] exercises power over [B] by influencing, shaping or determining his[/her] very wants' (Lukes 1974, 27), through indoctrination, acculturation and socialisation. Moreover, power is exercised in part through control of the institutions that shape and create meaning (Hinson and Healey 2003, 4). Lukes' invisible power is inspired by Gramsci's ideas of hegemony and the manufacture of consent. Lukes' conceptualisation of power is that of power as domination, characterised as power over. This contrasts with the alternative idea of power as empowerment, characterised as power to, as articulated by Arendt (1957 and 1970), Parsons (1963), Barnes (1988), and Searle (2007). For the purposes of this paper and due to the limitations of what can be substantively covered, I will concern myself with the idea of power as domination, by domination I mean obedience gained through compliance (Elias, 2000) rather than coercion, as I would characterise the relationship that exists between the British people and their government as power over.

Although it is true that governments are elected by the people and if the people dislike their government, they can vote for change at the following General Election, nevertheless, with the UK's first-past-the-post electoral system, there has been a rule of the minority since 1945, as no party has gained over $50 \%$ of the votes cast. Recent governments have not sought to 
build consensus for their policies, and matters are exacerbated by the increasingly executive style of government that exists in the UK, which has undermined parliamentary democracy. Liberal democracies such as that of the UK are representative democracies; but what happens when a representative democracy is unrepresentative and most of the power de facto is vested in the hands of the Executive? In such a climate there is very little the Legislature or the people can do to change government policy, especially if the government possesses a substantial parliamentary majority.

Now, let us examine how the academisation debate is framed by government, and how this message is delivered. First, both Labour and Conservative governments have been keen to promote ideas of greater choice and autonomy for the population (see the Ministry of Justice Green Paper The Governance of Britain (2007) on devolving power to local government, and the people). Visible power is used to frame conversion to academies as strengthening local democracy: the Academies Act 2010 specifies that 'before a maintained school in England is converted into an Academy, the school's governing body must consult such persons as they think appropriate' (my italics). However, hidden power is used to subvert this consultation process; evidence given to the Report on the MPs Committee of Enquiry into Academies and Trust Schools on January 122007 discloses 'rushed, flawed and manipulated consultation processes with a complete disregard of [the] views' of those against academisation. More worryingly there is evidence of Government itself trying to bypass consultation. For example, while Roke Primary School in Croydon was being primed for Academy conversion as part of the Harris chain, a letter sent from the Schools Minister, Lord Nash, to the local Conservative MP Richard Ottaway suggested parents, teachers and members of the local community would not be invited to give their views about the proposed conversion until after it had been agreed 
by the Department of Education. Worse still, the consultation was permitted to be carried out by Harris, who stood to gain from its successful conclusion. Lord Harris has history. In June 2007 he informed the Financial Times 'I have a very good relationship with Andrew (Lord Adonis, then Schools Minister). He rings me and says, "Do you want this school?" and I ask what it's like and if it sounds like the sort of place that we are interested in I say yes' (cited Wrigley 2009, 47; see also Benn 2008 for further examples of lack of transparency).

Second, the origins of academisation in England lie in the need to address 'failing' schools. From its inception, academisation has been about addressing failure. The use of hidden power has manipulated the debate by framing it around the idea that academisation is the only way to help failing schools. Here we see the hegemonic power (government) projecting its thinking upon the subordinated (citizens) to affirm the hegemonic ideology through false consciousness. The importance of language manipulation cannot be underestimated. Academies are associated with innovation and positivity; for example regarding the academisation of a school, the local Labour MP Siobhain McDonagh sent a questionnaire to the parents with the following tick box choices:

- Yes, I am in favour of raising standards at Mitcham Vale Tamworth Manor High School by getting academy status.

- No, I am against these changes to Mitcham Vale Tamworth Manor High School designed to improve examination standards (cited in Wrigley 2009, 58).

This is a brazen attempt to manufacture consent by coding a positive response with the raising of standards, and negative response with a desire not to improve. Professing to develop only 
evidence-based policies, David Blunkett the former Labour Education Secretary nevertheless forged ahead without waiting for the evidence expected from the PwC five-year evaluation study, asserting that: 'We cannot wait five years for the study. These children only get one life chance and we can't afford to wait that long before we make the radical break with the past, which academies represent' (quoted in Beckett 2007, 37). This is exercise of visible ministerial power as it subverts parliamentary due process, given that the PwC study had been commissioned by the House of Commons Education and Skills Select Committee (2005).

In addition, over time the concept of failure has been redefined and, in an example of visible power, the Education and Adoption Act 2016 will require all schools rated inadequate by Ofsted to become an Academy. The Act additionally extends the concept of failure to coasting schools, so that even schools performing well, but not improving, will be subject to compulsory academisation. This skilful use of hidden power to redefine the concept of failure implies that any school being converted must be a failing school. (It is interesting to note that no mechanism exists whereby a failing Academy may revert to local authority control). And any opposition to conversion will be negatively construed as an obstruction, and ignored. The effect of invisible power results in the acculturation of citizens to the belief that academisation is the only solution for failing schools.

Furthermore, the government has introduced yet another way to define failure - by attaching the concept not only to schools but also to local authorities (LAs). The Education for All Bill (2016), which tried to move the goalposts further by requiring all state maintained schools to be forced to become Academies, has been shelved (for the time being). There is further skulduggery afoot: at primary school level only 2,440 of 16,766 schools currently have 
Academy status. However, the recent introduction of more rigorous SATs exams for primary school children paves the way to classify schools as 'underperforming' and thus open to statutory academisation. I believe these new standards for SATs are a cynical attempt to guarantee 'failure' of primary schools, especially when these schools performed above the previous, government-set, standards in 2014. Last year's 'tough' SATs results show that only $53 \%$ of pupils passed (compared with $80 \%$ in 2015 ), the government expectation being $65 \%$ passing in each school (Richardson, 2016). Unfortunately, to discuss the effectiveness or otherwise of Academies using this form of 'evidence', is to fall into the trap of regarding the raising of standards as a uni-dimensional measure, i.e. attaining higher grades.

Hidden power has also been employed to:

- prevent conflict from arising, by controlling the terms of reference of the Academies Commission (Husbands et al., 2013). The Commission was not tasked to revisit the policy decisions to create and develop the Academies programme, "but rather to explore a future with a significantly or wholly academised system' (ibid.)

- ensure that consultation processes are restricted and manipulated to avoid the discussion of opposing views

- promote the mobilisation of bias, by the creation of the think tank Policy Exchange to conduct research and give academisation a semblance of academic respectability

- appoint individuals to strategic positions who share an ideology; for example, the chief inspector of Ofsted, Amanda Spielman, set up an Academy chain in 2004 and remains in a strategic role, but otherwise has no teaching qualifications

- finally hidden power conveniently ignores evidence of socio-economic status as a factor in educational attainment and life chances (Pickett and Wilkinson, 2007). 


\section{Possible repercussions of power}

Foucault's concept of 'docile bodies' (Discipline and Punish, 1979) says that people are and will be regulated in subtle, seemingly invisible ways leading to normalisation and acceptance of systems which do not promote their interests. This is done by governing the way that a 'topic' (Academisation) can be 'meaningfully talked about and reasoned about. It also influences how ideas are put into practice and used to regulate the conduct of others' (Foucault, in Hall, 1997: 72). People are controlled by the invisible hand of hegemonic power (government) exercised through State apparatuses, civil institutions such as think tanks, the media and certain academics aligned to corporate interests, to shape and create meaning.

In England, the purpose of education and schooling has changed without any 'Great Debate': education no longer seeks the cultivation of a person's humanity, of promoting social solidarity. Instead it has become perfectly 'common sense' to view the purpose of education through the egotistical lens of the individual, the economic imperative, and as just another commodity. 'Despite it being known that affluence does not breed contentment (Offer, 2006) the UK Government is forcing these political dogmas about how to achieve growth and value from academic study into the student's mindset' (Holligan and Chiang, 2011).

Under the above world view, teachers are seen as 'deliverers' of a curriculum, and need to be neither qualified nor experienced. Already, Academies and Free Schools are exempt from the obligation to employ teachers with Qualified Teacher Status (QTS) accreditation. Had the Education for All Bill (2016) not been dropped, it would have meant the accreditation of QTS 
status would have been at the headteacher's discretion; consequently, it would have become much easier and cheaper to hire unqualified teachers, and 'train' them. In the future one may well find a bank of lesson plans that anybody would be able to 'deliver' in a warm and pleasant manner (Holligan and Shah, 2017: 123). This is not far-fetched: an advocate of privatisation James Tooley, who runs schools in Africa, admits to hiring unqualified 'teachers' on low pay and that 'we create everything they need centrally - lesson plans, workbooks, exercises - and give them a three-week crash course' (Wilby, 2013).

A further example of teachers becoming 'deliverers' is to be found in that case of Future Academies, an MAT set up by Lord Nash (a government Minister for Academies) and his wife. The Trust had engaged a History graduate (Jo Nash) - without teaching qualifications - not only to advise on the curriculum and to engage in the recruitment of teaching staff, but also to teach History. This unqualified teacher was also unpaid, and supported in her voluntary capacity by her parents - Lord and Lady Nash. At the same time Jo Nash remained on the parliamentary Register of Interests, in the office of Sir lain Duncan Smith (a former government minister). In 2013 the same chain had engaged Annaliese Briggs, a 27-year-old head teacher, who subsequently joined the Policy Exchange think tank and co-authored the report Primary Focus.

It is not inconceivable that the proposals in the Education for All Bill will reappear at some later stage. Such a devaluing of teaching practice is a reflection of the market ethos being imputed upon education: seeing it as just another commodity that simply needs to be packaged nicely and uniformly no matter the substance (an analogy with supermarkets and their push for aesthetics at the expense of taste can be made). Consequently, the weight of 
'success' becomes defined in terms of examination results achieved by an individual, the professionalism of the teacher is seen through the narrow lens of what Giroux (1985) calls 'specialised technicians' (bureaucrats) tasked with 'managing and implementing curricula' 'deliverers' of results - rather than as 'transformative intellectuals' - capable of combining reflection and practice; enabling students to be 'thoughtful'.

\section{Possible societal consequences of Academisation}

Academisation raises the spectre of greater stratification of society and ethnic segregation, as evidenced in Sweden (Skolverket 1996, 2003, in Wiborg, 2010: 14). Lindbom and Almgren (2007, in ibid., 15) contest this and claim that housing is the single most important factor contributing to segregation, with Free schools accounting for only a very small proportion of increased school segregation. However, their claims are challenged by many other studies which identify greater segregation being attributable more to the result of school choice than to the effect of housing (Daun 2003; Arnman et al. 2004; Böhlmark and Lindahl 2007; Gustafson 2006, 2007; Bunar 2008, in ibid p, 14). In England there is already some evidence of academisation as a driver for segregation and selection (Green et al., 2015).

Academisation has the potential to impact negatively on social cohesion. For example, when a proportion of an Academy school's intake (presently 10\%) can be selected by ability, the definition of ability - and the contestability of that definition becomes important. Prime Minister Theresa May has a clear desire to introduce new grammar schools, and greater selection; ministers are encouraging Academies to set up more selective schools. Nick Gibb

told Academy bosses that government proposals were 'asking how some existing non- 
selective schools, including Academies, could become selective - if they wish.' 'Some of the schools in your trust may wish to introduce selection by ability.' Or trusts 'may consider establishing a new selective free school or you may look to expand using the routes that are already available' (Gibb 2016, in Richardson, 2016). Furthermore, the idea of separate units for high-ability pupils is also under consideration.

A shift towards greater selection by ability is supported by the switch from a binary pass/fail result at Key Stage 4 (KS4: assessing the two years of state maintained school education leading to and incorporating GCSEs and other examinations in England) to the publication of individual scores, either as a number or as a percentile of the national distribution of these results. This has opened the way for the development of classification systems to support selection criteria to individual secondary schools within a multi-academy trust (MAT). It is easy to envisage a system in which those schools available to a child will depend on the band into which their KS4 results sit - with such banding being set independently by each MAT. This has the potential to further compound societal stratification and social cohesion rather than enhance social mobility, especially given the situation in higher education. With rising tuition fees, and the prospect of debts akin to second mortgages, many working-class students are already dissuaded from studying at universities, especially as they lack the social capital to access the 'lucrative employment opportunities [...] available to the other social strata' (Holligan and Chiang, 2011: 242). The Social Mobility and Child Poverty Commission 2015 report found that in the UK, social mobility is lower than in most other comparable countries in the OECD. 
Academisation arguably represents the privatisation of a public service (Ball 2007; Beckett 2007, in Hatcher 2008, 21). It is a corporate takeover leading to what Ball (2003, in Holligan and Chiang, 2011) terms an 'endogenous' form of market-led remodelling, that is to say: the remnants of the public sector, metamorphosing into the values and identities of the corporate state. This radical shift in educational policy has taken effect without substantive debate taking place concerning the change. The dismantling of the national system of public schooling provided by the state 'is beginning to resemble the patchwork of uneven and unequal provision that existed prior to the 1870 Education Act' (Ball, 2013). This ideological push for the academisation of schools could lead to myriad organisations running state schools. It is only a matter of time before private providers will be given the opportunity to profit from running schools (as in Sweden and the US). Under the guise of parental choice, and greater school autonomy, academisation is undermining local democracy. If we are to go down the path of Sweden then there should be an open and transparent debate about the possible consequences of such a model, for the kind of schooling one receives has implications for one's education. For example the narrow focus on skills and Science, Technology, Engineering and Mathematics in schools arguably comes at the expense of students' moral and civic development.

In some respects it could be argued that academisation represents the independence of education, free of political interference. However, the Swedish experience would suggest the consequence of academisation is not without cost: the raising of standards is not guaranteed, and in fact the opposite may be possible. Sweden again provides a worrying example: of bankruptcy. In 2013, JB Education, owned by the Danish private equity company Axcel, became bankrupt leaving a debt of $\$ 150$ million. In England, who would foot the bill? And 
what would happen to students and teachers whilst a new MAT was found to take over the affected schools? The failure of Perry Beeches Trust in Birmingham, once the leading light of academisation, raises such a spectre. The collapse of the trust due to serious financial mismanagement (EFA, 2015) leaves its five schools, with estimated debts of $£ 1.8$ million, facing an uncertain future while other MATs are found to take over the individual schools.

With full academisation and corporatisation of schooling, it is not difficult to then see its actual privatisation, in which MATs are allowed to make a profit. The spectre also arises of what is offered as a curriculum being linked to the ability to pay. The Latymer School in north London has requested annual contributions from parents in order to maintain the subjects it offers (Adams, 2016). This school is not alone in seeking parental contribution for non-capital expenditure. This could lead to differentials in standards of education being provided to students. Such differentials would undermine the ethos 'of entitlement to a broad and balanced curriculum for all pupils regardless of ability', ... [which was the purpose of comprehensive education] to provide common schooling 'to all sections of society' (Titcombe 2008, 49).

\section{Conclusion}

Academisation is ideologically driven by the market-oriented socio-politico-hegemony that has taken root in England since the 1980s. Academisation is a deeply contested field yet successive governments act as if the case for academisation has been made - a perfect example of the use of hegemonic power. It shows disregard for the wishes of citizens, and for the body of evidence against the perceived benefits of academisation. Those who exercise 
hegemonic power in its different forms (visible; hidden; invisible) have sought to control and subvert the debate around the merits of academisation; redefining concepts of failure; marginalising those voices against it, and excluding them from the decision-making processes, or by offering only tokenistic consultation (Arnstein, 1969). This sense of powerlessness becomes internalised and seen as the 'natural state' of things.

It would be wrong to pretend that education has ever been independent of powerful influences, nor do I advocate an education system divorced from society at large, run only by educational 'experts' for no single group can be trusted to safeguard an education that is truly free of ideological interference. British governments have a stranglehold over educational policy in England, and given the partisan nature of British politics this is bad for society. Decisions about education are taking place in a secret garden comprising the few, motivated by short-termism, political expediency and ideological preferences. Education is fundamental to the kind of society that we wish to create, and has implications for human rights, citizenship and democracy; education should not be treated like any other commodity, for unlike other commodities. It is neither easy to quantify nor to 'succinctly specify ... the good at the heart of [...] education' (Staddon and Standish, 2012: 635); nor should it ever be allowed to be controlled by any one group in society, whether politicians or otherwise. 


\section{References}

Adams R (2016) Latymer grammar school asks parents to make up financial shortfall. The Guardian. Available from:

https://www.theguardian.com/education/2016/oct/02/latymer-school-grammarparents-financial-shortfall-theresa-may-education-policy (accessed 14 January 2017).

Angel Solutions Ltd (2016) Inspection Statistics: LA Maintained Schools and Academies. Liverpool. Available from:

www.local.gov.uk/documents/10180/11411/Academies+and+LA+maintained+schools+ FINAL/ecd8514e-97a2-4d09-ae08-769c591acbf4 (accessed 20 July 2016).

Arendt H (1957) The human condition. Chicago, IL: Chicago University Press.

Arendt H (1970) On violence. Harmondsworth: The Penguin Press.

Arnstein SR (1969) A Ladder Of Citizen Participation. Journal of the American Institute of Planners, Taylor \& Francis Group 35(4): 216-224. Available from: http://www.tandfonline.com/doi/abs/10.1080/01944366908977225 (accessed 11 July 2014).

Bachrach P and Baratz MS (1962) Two Faces of Power. American Political Science Review, Cambridge University Press 56(4): 947-952. Available from: http://www.journals.cambridge.org/abstract_S0003055400000046 (accessed 18 July 2016).

Ball SJ (2004) Education for sale! The commodification of everything? King's Annual Education Lecture, London: University of London. Available from: http://sys.glotta.ntua.gr/Dialogos/Politics/CERU-0410-253-OWI.pdf (accessed 29 April 2016).

Ball SJ (2007) Education plc : understanding private sector participation in public sector 
education. Routledge. Available from: http://eprints.ioe.ac.uk/4625/ (accessed 7 May 2017).

Ball SJ (2013) Free schools: our education system has been dismembered in pursuit of choice. The Guardian. Available from: http://www.theguardian.com/commentisfree/2013/oct/23/education-systemdismembered-choice (accessed 29 April 2016).

Barnes B (1988) The nature of power. Cambridge: Polity Press.

Bassey M (2003) More advocacy: give autonomy back to teachers. Research Intelligence. Available from: https://www.bera.ac.uk/wp-content/uploads/2016/07/BERARI084.pdf. Beckett F (2007) The great city academy fraud. Bloomsbury Academic. Blomqvist P (2004) The Choice Revolution: Privatization of Swedish Welfare Services in the 1990s. Social Policy and Administration, Blackwell Publishing Ltd 38(2): 139-155. Available from: http://doi.wiley.com/10.1111/j.1467-9515.2004.00382.x (accessed 20 July 2016).

Blunkett D (2010) Speech to Social Market Foundation. 15th March.

Briggs A and Simons J (2014) Primary Focus: The next stage of improvement for primary schools in England. London: Policy Exchange. Available from: https://policyexchange.org.uk/wp-content/uploads/2016/09/primary-focus.pdf.

Chubb JE and Moe TM (1990) Politics, markets, and America's schools. Washington DC: Brookings Institution.

Connell R (2013) The neoliberal cascade and education: an essay on the market agenda and its consequences. Critical Studies in Education, Routledge 54(2): 99-112. Available from: http://www.tandfonline.com/doi/abs/10.1080/17508487.2013.776990?journalCode=rc se20 (accessed 21 July 2016). 
Cox CB and Boyson R (eds) (1977) Black Papers 1977. London: Maurice Temple Smith.

Dahl R (1961) Who governs? : democracy and power in an American city. New Haven: Yale University Press.

DfE (2016) Schools, pupils and their characteristics : January 2016 [SFR 20/2016]. London.

Available from:

https://www.gov.uk/government/uploads/system/uploads/attachment_data/file/5523

42/SFR20_2016_Main_Text.pdf (accessed 7 June 2017).

EFA (2015) Financial management and governance review: Perry Beeches The Academy Trust Final report. London. Available from:

https://www.gov.uk/government/uploads/system/uploads/attachment_data/file/5105 09/Financial_management_and_governance_review_Perry_Beeches_The_Academy_Tr ust.pdf (accessed 7 June 2017).

Elias N (2000) The civilizing process : sociogenetic and psychogenetic investigations. 2nd ed. Blackwell Publishers.

Foucault M (1979) Discipline and punish : the birth of the prison. trans. Alan Sheridan (ed.), Harmondsworth: Penguin Books.

Francis B, Hutchings M and de Vries R (2014) Chain Effects: The impact of academy chains on low income students. London: The Sutton Trust. Available from:

http://www.suttontrust.com/researcharchive/chain-effects/.

Friedman M (1962) Capitalism and freedom. Chicago: University of Chicago Press.

Gibb N (2015) The importance of the teaching profession. London: Speech to the ResearchED conference. Available from:

https://www.gov.uk/government/speeches/nick-gibb-the-importance-of-the-teachingprofession. 
Giroux HA (1985) Teachers as Transformative Intellectuals. Social Education 49(5): 376-79. Available from: http://eric.ed.gov/?id=EJ317521 (accessed 29 April 2016).

Goldring E and Mavrogordato M (2011) International perspectives on academies: Lessons learned from charter schools and choice options around the globe. In: Gunter HM (ed.), The state and education policy: The academies programme, Continuum, pp. 185-198.

Gorard S (2014) The link between Academies in England, pupil outcomes and local patterns of socio-economic segregation between schools. Research Papers in Education, Routledge 29(3): 268-284. Available from: http://www.tandfonline.com/doi/full/10.1080/02671522.2014.885726 (accessed 21 July 2016).

Green F, Allen R and Jenkins A (2015) Are English free schools socially selective? A quantitative analysis. British Educational Research Journal 41(6): 907-924. Available from: http://doi.wiley.com/10.1002/berj.3190 (accessed 21 July 2016).

Gunter HM (2011) Introduction: Contested Educational Reform. In: Gunter HM (ed.), The state and education policy: The academies programme, Continuum, pp. 1-18.

Gunter HM and McGinity R (2014) The politics of the Academies Programme: natality and pluralism in education policy-making. Research Papers in Education 29(3): 300-314. Available from: http://www.tandfonline.com/doi/abs/10.1080/02671522.2014.885730 (accessed 20 July 2016).

Hall S (1997) The work of representation. In: Hall S (ed.), Representation: cultural representations and signifying practice., London: SAGE Publications, in association with the Open University.

Hatcher R (2008) Selling Academies: local democracy and the management of 'consultation'. Journal for Critical Education Policy Studies 6(2): 21-36. Available from: 
http://www.jceps.com/archives/tag/volume-6-number-2.

Hatcher R (2011) Local Government Against Local Democracy: A Case Study of a Bid for Building Schools for the Future Funding for an Academy. In: Gunter HM (ed.), The State and Education Policy: The Academies Programme, Continuum.

Hinson S and Healey R (2003) Building Political Power. Strategic Practice: Grassroots Policy Project, Cambridge, MA. Available from:

http://www.strategicpractice.org/system/files/building_political_power_0.pdf.

Holligan C and Chiang K-H (2011) Browne's Capgas Delusion: The Destruction of the Public University. Journal for Critical Education Policy Studies 9(2): 241-259. Available from: http://www.jceps.com/archives/684 (accessed 3 May 2016).

Holligan C and Shah Q (2017) Global capitalism's Trojan Horse: Consumer power and the National Student Survey in England. Power and Education, SAGE PublicationsSage UK: London, England 9(2): 114-128. Available from: http://journals.sagepub.com/doi/10.1177/1757743817701159 (accessed 19 January 2018).

House of Commons Education and Skills Select Committee (2005) Secondary Education. Fifth Report of Session 2004-05. London: The Stationery Office Limited. Available from: https://www.publications.parliament.uk/pa/cm200405/cmselect/cmeduski/86/8602.ht m (accessed 17 May 2017).

House of Commons Education Committee (2015) Academies and free schools. Fourth Report of Session 2014-15. London: The Stationery Office. Available from: http://www.publications.parliament.uk/pa/cm201415/cmselect/cmeduc/258/258.pdf (accessed 20 July 2016).

Husbands C (2016) The 2016 Education White Paper - a response. Available from: 
https://www.bera.ac.uk/blog/the-2016-education-white-paper-a-response.

Husbands C, Gilbert C, Francis B, et al. (2013) Unleashing Greatness: Getting the best from an academised system. The Report of the Academies Commission. London. Available from: https://www.thersa.org/globalassets/pdfs/reports/unleashing-greatness.pdf.

Jeffs T and Smith MK (2002) Individualization and youth work. Youth and policy 76: 39-65.

Available from: http://www.infed.org/archives/e-

texts/individualization_and_youth_work.htm (accessed 29 April 2016).

Keep E (2006) State control of the English education and training system - playing with the biggest train set in the world. Journal of Vocational Education and Training, Routledge 58(1): 47-64. Available from:

http://www.tandfonline.com/doi/abs/10.1080/13636820500505819 (accessed 21 July 2016).

Kimber R (2012) Share of seats and votes in UK General Elections since 1945. Available from: http://www.politicsresources.net/area/uk/percentvote.htm (accessed 29 April 2016).

Lukes S (1974) Power: A Radical View. 2nd ed. Basingstoke: Palgrave Macmillan.

Machin S and Wilson J (2009) Public and Private Schooling Initiatives in England. In:

Chakrabarti R and Peterson P (eds), School Choice International: Exploring Public-Private Partnerships, MIT Press, pp. 219-244.

Manin B (1997) The Principles of Representative Government. Cambridge: Cambridge University Press. Available from:

https://books.google.co.uk/books/about/The_Principles_of_Representative_Governm. html?id=GhAJ2×2coEoC\&pgis=1 (accessed 29 April 2016).

Martin I (2003) Adult education, lifelong learning and citizenship: some ifs and buts. International Journal of Lifelong Education, Taylor \& Francis Ltd 22(6): 566-579. 
Available from: http://www.tandfonline.com/doi/abs/10.1080/0260137032000138130 (accessed 1 February 2016).

OECD (2015) Improving Schools in Sweden: An OECD Perspective. Paris. Available from:

http://www.oecd.org/edu/school/Improving-Schools-in-Sweden.pdf.

Offer A (2006) The Challenge of Affluence. The Challenge of Affluence, Oxford University Press. Available from:

http://www.oxfordscholarship.com/view/10.1093/acprof:oso/9780199216628.001.000 1/acprof-9780199216628 (accessed 20 July 2016).

Oxford Dictionaries (n.d.) Oxford Dictionaries. Oxford University Press. Available from: http://www.oxforddictionaries.com/definition/english/academy.

Parsons T (1963) On the Concept of Political Power. Proceedings of the American Philosophical Society 107(3): 232-262. Available from: http://www.jstor.org/stable/985582.

Perry E and Francis B (2010) The Social Class Gap For Educational Achievement: a review of the literature. London: RSA. Available from: https://www.thersa.org/globalassets/pdfs/blogs/rsa-social-justice-paper.pdf.

Pickett KE and Wilkinson RG (2007) Child wellbeing and income inequality in rich societies: ecological cross sectional study. BMJ (Clinical research ed.), British Medical Journal Publishing Group 335(7629): 1080. Available from:

http://www.ncbi.nlm.nih.gov/pubmed/18024483 (accessed 22 July 2016).

Polsby NW (1963) Community power and political theory. New Haven: Yale University Press. PwC (2008) Academies Evaluation: Fifth Annual Report. Annesley: DCSF Publications. Ranson S (1993) Markets or Democracy for Education. British Journal of Educational Studies 41(4): 333. Available from: http://www.jstor.org/stable/3121957?origin=crossref 
(accessed 7 May 2017).

Ranson S (1995) Public Institutions for Cooperative Action: A Reply to James Tooley. British Journal of Educational Studies 43(1): 35. Available from:

http://www.jstor.org/stable/3121755?origin=crossref (accessed 7 May 2017).

Richardson H (2016) Academies encouraged to open selective schools. BBC, BBC. Available from: http://www.bbc.co.uk/news/education-37451974 (accessed 14 January 2017).

Searle JR (2007) Social ontology and political power. In: Freedom and neurobiology: reflections on free will, language and political power, New York, NY: Columbia University Press, pp. 79-110. Available from:

http://www.jstor.org/stable/10.7312/sear13752.5.

Social Mobility and Child Poverty Commission (2015) State of the Nation 2014: Social Mobility and Child Poverty in Great Britain. London: Her Majesty's Stationery Office. Available from: https://www.gov.uk/government/publications/state-of-the-nation2014-report.

Staddon E and Standish P (2012) Improving the Student Experience. Journal of Philosophy of Education 46(4): 631-648. Available from: http://doi.wiley.com/10.1111/j.14679752.2012.00885.x (accessed 1 September 2016).

TES Reporter (2015) Even 'good' schools could be forced to become academies, PM warns. TES. Available from: https://www.tes.com/news/school-news/breaking-news/evengood-schools-could-be-forced-become-academies-pm-warns (accessed 22 July 2016). Titcombe R (2008) How Academies Threaten the Comprehensive Curriculum. FORUM 50(1): 49. Available from: http://www.wwwords.co.uk/rss/abstract.asp?j=forum\&aid=3194\&doi=1 (accessed 7 May 2017). 
Tooley J (1995) Markets or Democracy for Education? A Reply to Stewart Ranson. British Journal of Educational Studies 43(1): 21. Available from: http://www.jstor.org/stable/3121754?origin=crossref (accessed 7 May 2017).

Walford G (2014) Academies, free schools and social justice. Research Papers in Education 29(3): 263-267. Available from:

http://www.tandfonline.com/doi/abs/10.1080/02671522.2014.885725 (accessed 20 July 2016).

Weale S (2015) Education secretary raises the bar with new 'coasting schools' criteria. The Guardian, 30th June. Available from:

http://www.theguardian.com/politics/2015/jun/30/nicky-morgan-coasting-schoolscriteria (accessed 22 July 2016).

West A (2014) Academies in England and independent schools ( fristående skolor ) in Sweden: policy, privatisation, access and segregation. Research Papers in Education 29(3): 330-350. Available from:

http://www.tandfonline.com/doi/abs/10.1080/02671522.2014.885732 (accessed 21 July 2016).

Wiborg S (2010) Swedish Free Schools: Do they work? Centre for Learning and Life Chances in Knowledge Economies and Societies. Available from: http://www.llakes.org/wpcontent/uploads/2010/09/Wiborg-online.pdf (accessed 22 July 2016).

Wilby P (2013) James Tooley: A champion of low-cost schools or a dangerous man? | Education | The Guardian. The Guardian. Available from: https://www.theguardian.com/education/2013/nov/12/professor-james-tooley-lowcost-schools (accessed 17 May 2017).

Worth J (2015) Analysis of academy school performance in GCSEs 2014: Final report. Slough: 
NFER and Local Government Association. Available from:

https://www.nfer.ac.uk/publications/LGGA03/LGGA03_home.cfm.

Wrigley T (2009) Academies: privatising England's schools. Soundings 42(1): 47-59. Available from: http://openurl.ingenta.com/content/xref?genre=article\&issn=1362-

6620\&volume=42\&issue=1\&spage=47 (accessed 7 May 2017). 